\title{
Assessing the maturity level of foresight in Polish companies-a regional perspective
}

\author{
Anna Kononiuk ${ }^{1}$ • Anna Sacio-Szymańska ${ }^{2}$
}

Received: 1 September 2015 / Accepted: 27 November 2015 / Published online: 4 January 2016

(C) The Author(s) 2016. This article is published with open access at Springerlink.com

\begin{abstract}
In the face of accelerated change and genuine uncertainties in the business environment as well as the need of processing and interpreting the information coming from majority of sources, foresight research in the enterprises comes into prominence. The main aim of the article is to assess foresight maturity of companies based in Podlaskie province in Poland as one of the least developed regions in Europe. The survey research is preceded by bibliometric analysis and literature review to examine current tendencies in foresight research in organisations. The conclusions drawn from the analysis of the existing works on organizational foresight are that foresight is no longer referred to only as a portfolio of methodologies through which organizations may garner a broader vision and probe the future to ascertain potential competitive landscapes but also as a human or organisational competence. Therefore, the research is based on a foresight maturity model developed by Grim (J Futur Stud 13(4):69-80, 2009). The model, besides traditionally associated foresight components such as environmental scanning, takes into consideration such aspects as leadership, collective vision building, and planning. Pilot survey research carried out among 134 production and services enterprises based in the Podlaskie region has allowed us to state that the companies are characterised by low foresight maturity levels. Hence, based on a literature review, two management concepts are suggested as means to increase the level of foresight maturity in companies.
\end{abstract}

Anna Sacio-Szymańska anna.sacio@itee.radom.pl

1 Bialystok University of Technology, Bialystok, Poland

2 Institute for Sustainable Technologies - National Research Institute, Radom, Poland
Keywords Foresight maturity $\cdot$ Corporate foresight $\cdot$ Maturity models · Poland · Podlaskie region - Empowerment ·

Organizational culture

\section{Rationale and research purpose}

The number of articles considering foresight in the refereed foresight journals, such as Technological Forecasting and Social Change, Futures, and Journal of Futures Studies, is still increasing. A detailed account of the evolution of the corporate foresight field has been recently given by Rohrbeck et al. [1]. The main themes touched upon by the authors of the articles related to corporate foresight concern (i), innovation management in the aspect of radical innovations $[2,3]$ and disruptions, (ii) change management [4], (iii) scanning and the uncertainty of the environment [5], and (iv) decision taking [6] and strategic management [7]. Existing published works on foresight in enterprises use notions such as corporate foresight [8,9], strategic foresight [10], and business foresight [11]. The terms strategic, organizational, business or corporate foresight have been used to describe futures research activities in corporations [3] or organizations. (It has been argued that these terms can be used somewhat synonymously [12]). Vecchiato and Roveda [13] use strategic foresight deliberately to emphasize the tight relationship between foresight and strategy formulation. According to Rohrbeck [9], organizational foresight is "an ability that includes any structural or cultural element that enables the company to detect continuous change early, interpret the consequences for the company, and formulate effective responses to ensure the long-term survival and success of the company".

The potential benefits of the application of foresight in business practice embrace the following: the ability to spot and interpret environmental changes [14]; the enhancement 
of strategic planning processes [15]; and, the increase of innovative capabilities [16]. The confirmation of the benefits mentioned above is in the empirical research carried out by Rohrbeck and Schwartz [17] in 77 enterprises. The authors, basing their research on organizational models describing the enterprise as an interpretative system [18], prove that the formalized process of foresight increases the ability of the following:

- Unprecedented events and trends detection,

- Changes interpretation,

- Reaction to changes,

- Organizational learning, and

- Influencing the decision of co-working entities.

In the context of the three major steps of the foresight process, consisting of (1) the collection of information, (2) interpretation, and (3) utilization, a company would need relevant skills to find, filter, interpret, and use future relevant data in managerial practice and would require the access to relevant sources of information about possible futures. This understanding is echoed by Lichtenthaler [19] stating that the effectiveness of technology management is fundamentally influenced by the quality of a firm's technology intelligence process, i.e., the acquisition and assessment of information on technological trends.

More specifically, according to Rohrbeck et al. [20], five factors can be listed that have an impact on the success of foresight. These are the following:

- Information usage, which comprises information sources and information gathering methods;

- Method sophistication, how methods are chosen and used;

- $\quad$ People and networks, qualities of foresight staff;

- Organisation of foresight activities within companies; and,

- Culture; how supportive is the corporate culture towards foresight activities?

Having been motivated to use foresight to aid the strategic management process, companies may follow one or combine two of the following organisational approaches [21]:

1) A company might introduce foresight processes internally and/or

2) A company might internally use the results from foresight activities performed by other actors.

The main benefit of the first approach is that it is tailormade to the objectives of a single company in terms of foresight outcomes achieved and it provides additional value stemming from the foresight process, which, if set up on a continuous basis, may itself become another key competence and advantage of a company. The main disadvantages could be associated with greater resources (human, financial) to be committed. Also depending on internal competences, this option might require assistance from external facilitators or advisors (private foresight consultancies).

The second approach includes using data (e.g., surveys, Delphi results) from national, regional, or sectoral foresight activities for business and especially for strategic planning purposes. Since the data is more general in nature, companies must adapt them to their different uses and purposes in order to achieve the desired impact. A critical issue related to this second approach is making sure that the foresight results used by a company, the so-called "one-fits-all information package, " meet futures quality standards criteria [22, 23]. In addition, a valuable tool to evaluate the relevance of information about possible futures could be the Futures Map [24], which is defined as "the comprehensive description of the outcomes of futures research process." It provides validity criteria (internal and external ones), which make it possible (1) to evaluate the quality of the process that produces the map and (2) to assess the information content of the map and the usefulness of the content to the customers of the map.

Considering the above, many projects have been set up by national and local governments with the aim to disseminate foresight methodology and build a foresight culture among companies. The examples include the following:

- UK Foresight Training Toolkit [25] (a set of workshops and training materials offered to SMEs) and applied in Scotland, Northern Ireland and the West Midlands, ${ }^{1}$

- Finnish Uusimaa Employment and Economic Development Centre (EEDC ${ }^{2}$ ) project [27],

- Danish Technology and Enterprise in the Future project carried out in co-operation with the Confederation of Danish Industries (Dansk Industri) and the Central Organisation of Industrial Employees in Denmark (COIndustri) [28].

Similar projects addressed to companies are also run by private consultancies or non-profit organizations. They usually aim at helping enterprises define their strategy, assess a company's strengths and weaknesses, make use of opportunities, and avoid threats by advising them to find and interpret trends that are applicable for their line of business. Examples

\footnotetext{
${ }^{1}$ Over 3000 SMEs were advised over the 2 years of the programme's first phase, in 200 of them, in-company foresight exercises were conducted. ([26], pp. 21-22)

${ }^{2}$ The results of the project were used in the planning of further training for employees and in the planning of supporting activities for SMEs. Two follow-up projects were started for the support and development of enterprises, one for start-up businesses, and the other for fast-growing businesses. ([27], p. 190-197).
} 
of such initiatives include the initiative undertaken by SYNTENS [29], a Dutch non-profit organization, which developed a set of tools and methods (called ToekomstWijzer) that aimed to encourage and help SMEs 'look' into the future and make business strategies and new policy choices based on external trends and signals.

Finally, the following are some examples of national foresight projects/studies, ${ }^{3}$ the results of which could be used on a corporate level:

- The well-grounded Japanese foresight programme [31],

- The German BMBF foresight process 2007-2009 [32], and

- The study of the radical technologies of the future commissioned by the Parliament of Finland's Committee for the Future in 2013 [33].

Specifically, the methodological approach developed and implemented in Finland (named Radical Technology Inquirer) seems to appropriately address the needs of companies, since it lists the 100 most promising Radical Technological Solutions (RTS) in the context of the 20 Global Value Producing Networks (GVPN). A company might take the RTS from the reference list and evaluate technologies of its technology portfolio in the frame defined by the GVPNs to decide whether they are worth investing in [33].

Based on the presented conclusions and preliminary work, the rationales for this research are as follows:

- An increase in popularity as well as the confirmed effectiveness of foresight research conducted in or for companies which have been reported in key futures research journals;

- The documented beneficial influence of foresight research conducted in companies on skills improvement in the area of creating product, process and service innovations by companies, both incremental and radical;

- Support in the process of building a consistent reconfiguration of companies' strategic resources, which determine their competitive advantage;

- The opportunity of filling the gap in assessing foresight maturity in companies based in an under-developed region in Europe; and,

- The lack of research on foresight activities in Polish companies.

The main research purpose was to assess foresight maturity of companies based in Podlaskie province in Poland as one of the least developed regions in Europe. The pilot study was carried out in 2014. One hundred thirty-four enterprises

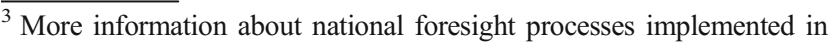
various countries is given in [30].
}

agreed to take part in the study. The selection of the researched companies was based on convenience sampling, which is a non-probability sampling technique where subjects are selected because of their convenient accessibility and proximity to the researcher.

The following four research questions were used to guide the research:

- What are the current tendencies of corporate foresight research?

- How does one assess foresight maturity of companies?

- What is the foresight maturity of companies based in the Podlaskie region in Poland?

- What management practices could be used to improve the foresight maturity of companies based in less developed regions?

The research process comprised six research stages.

In the first stage, a bibliometric analysis based on the SCOPUS database is carried out. Secondly a literature review on foresight in enterprises follows using EBSCO, Elsevier Science Direct, Springer and Emerald databases. In the third stage, the foresight maturity model FMM [34] is presented. The fourth stage introduces the characteristics of the Podlaskie region based on statistical data. The fifth stage is devoted to survey research with the aims of (1) determining the prevalence of foresight research in the Podlaskie region and (2) evaluating the foresight maturity level of manufacturing and service enterprises in the Podlaskie region. The final stage of the research is devoted to developing recommendations for further research.

\section{Bibliometric analysis}

The literature review was preceded by a bibliometric analysis based on the SCOPUS database, which enabled the authors of the article to indicate the tendencies in the field of strategic foresight research. The selection of the following database was determined by its availability. The authors collected articles from the period 1987-2015. For the purpose of the research, the authors created a database containing 379 scientific articles, 93 conference papers, 56 reviews, 17 book chapters, and 14 articles in press containing the phrase "strategic foresight." The majority of the articles came from leading foresight journals, such as Technological Forecasting and Social Change (75 articles), Foresight (59 articles), Futures (43 articles), Technology Analysis and Strategic Management (14 Articles), Futuribles Analyse Et Prospective (13 articles), and Journal of Futures Studies (13 articles).

For the purpose of the bibliometric analysis, the authors of the article applied VOS, which is a mapping technique that can serve as an alternative to the well- 
known technique of multidimensional scaling (MDS). VOS stands for visualization of similarities and has been used for constructing bibliometric maps in a number of studies [35-40].

The analysis was supported by VoSViewer software [35]. The authors carried out a co-word analysis in relation to titles, abstracts, keywords, and index words from the researched period of time and applying a methodology by Dobrzynski, Dziekonski, and Jurczuk [41]. The above mentioned set of data was the subject to a two-stage preliminary analysis - the automatic exclusion of selected English words such as prepositions and articles as well as the exclusion of words was carried out by the authors of the article on the basis of their expertise in the field of foresight research. Words such as author, aim, and result, to name but a few, and other extraneous terms were excluded. In the first phase of the preliminary analysis, of 12,859 terms, 330 met the threshold of 10 , which was the minimum number of occurrences of a term. In the second phase, 272 terms were left (58 words were excluded by the authors of the article). The results of the analysis are presented in Fig. 1.

The colour of a point on the map is close to the colour of a certain cluster if there are a large number of items belonging to that cluster in the neighbourhood of the point. The larger the number of items in the neighbourhood of a point, the closer the colour of the point is to red. Conversely, the smaller the number of items in the neighbourhood of a point, the closer the colour of the point is to blue. The size of a circle reflects an item's total number of co-occurrences [39]. Based on the data presented in the Fig. 1, some tendencies might be observed. First of all, one can identify three main clusters of terms' co-occurrences. The first one is located around the word implication, which co-occurs most frequently with such words as technology foresight, economy instrument, foresight study, and society. The authors presume that the terms may originate from articles focusing on the description of experiences with technology foresight applications for the enhancement of various sectors, regions, countries, etc. The words located around the term strategic foresight form the greatest cluster. As can be seen, the term itself co-occurs most frequently with the terms such as company, market, product, person, and ability. The qualitative analysis of the articles from the leading journals presented in the next section of this article confirms that foresight is no longer referred to only as a portfolio of methodologies through which an organization may garner a broader vision of the future to ascertain potential competitive landscapes [10, 16], but rather an ability that includes any structural or cultural element that enables the company to detect continuous change early, interpret the consequences for the company and formulate effective responses to ensure the long term survival and success of the company [9]. The third cluster is formed around the word manager that co-occurs with terms such as organization and theory. The authors of this article assume that these terms may originate from the articles aiming at advancing the theory of management, but further qualitative analysis is needed in this respect.

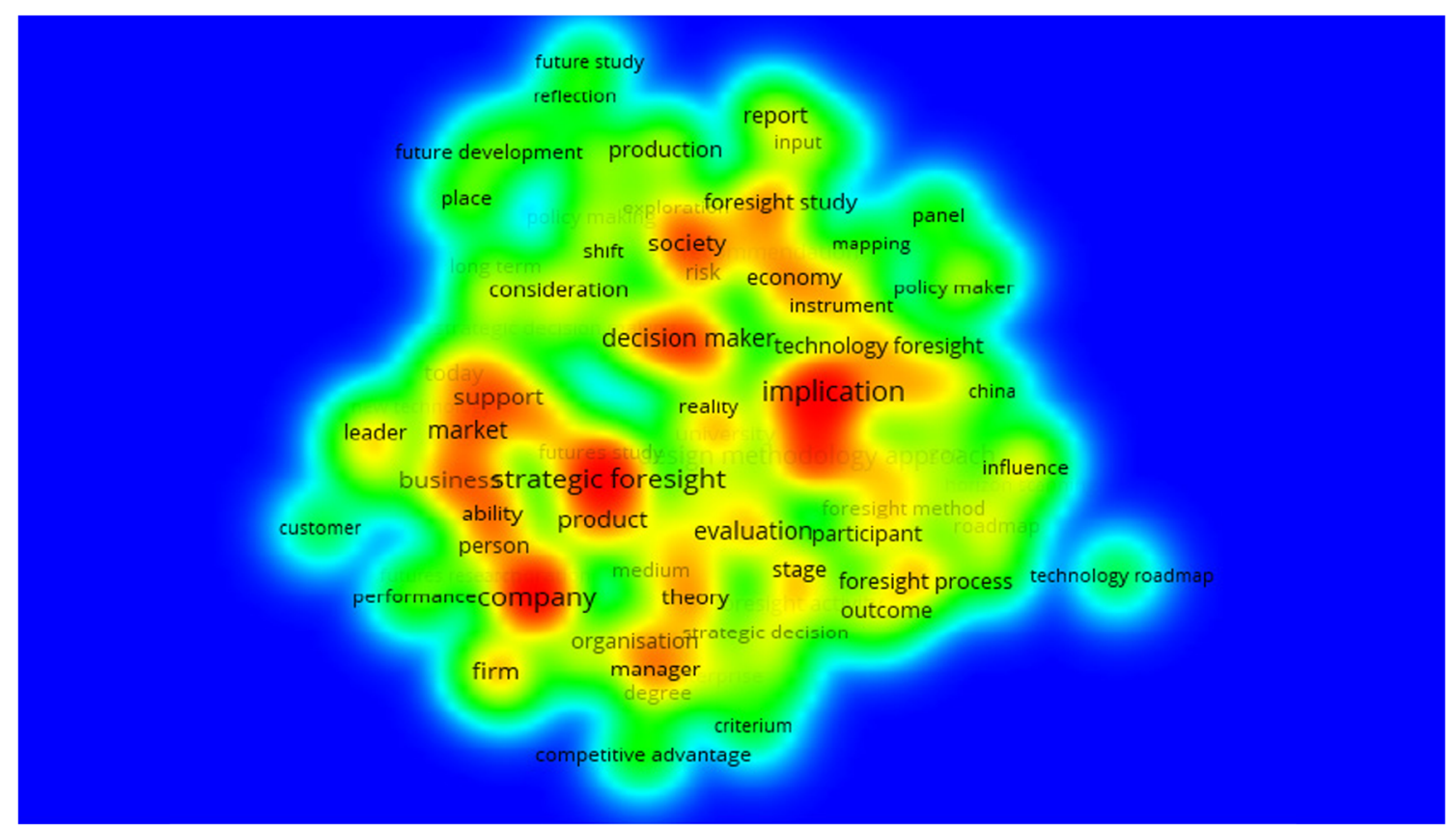

Fig. 1 A co-word analysis of the term strategic foresight density visualization carried out based on the articles from the 1987-2015 period (Source: Authors) 


\section{Literature review on the links between foresight, strategy, and organizational culture}

In the literature, foresight is often portrayed as a technical and analytic process [42], where the focus is put more on methods, methodologies, or systems developed and applied in various contexts (national, regional, sectorial, organisational) depending on the context of a specific foresight exercise. This approach can be justified regarding foresight executed on macro levels, where the main aims of foresight exercises focus rather on the foresight outcomes and not the foresight process itself as it usually takes place when organisational foresight is considered. It is in business environments where the role of individuals is pivotal to the building of a company's competitive advantage based on foresight as one of its core competences. As underlined by Vechiato, Roveda [13] and Thom [43]:

\section{"The real challenge of strategic foresight is ... most of all to reshape the strategic beliefs of managers. More explicitly: the real purpose of foresight is not to predict how a driver of change will evolve, but to change the mental models that decision makers carry in their heads" ([13], p. 1532). \\ "Depending on the attitude inside a company toward sharing of information, valuing this information and accepting the need for changes foresight results will be used-or not" ([43], p. 61).}

Among authors who analysed foresight in an organisation mostly as human or organisational competences are Major et al. [44], Cunha et al. [42], and Bootz [45].

Major et al. relate foresight to the core competence view of strategy, and they cite Slaughter [46], who describes foresight as an attribute, or a competence, that broadens the boundaries of perception. In addition, they refer to Prahalad and Hamel [47], according to whom core competencies are the collective learning in the organisation on how to coordinate production skills and technologies. They reason that firms can build a competitive advantage for the future only if they are able to successfully integrate individuals' foresight competence with the firms' skills and technologies. This reasoning comes from the results of their empirical work, which involved a research study comprised of interviews in 49 UK-based SMEs. The aim of the study was to achieve the following: to specify how small companies learn and acquire new knowledge, to assess their knowledge about the national UK foresight programme, and to evaluate human competence concepts of foresight. They conclude that the role of individual managers is crucial in foresight because their managerial attitudes to the future are the stimulus for the companies' foresight inclinations. In addition to empirical work, they analysed the strategy literature on core competencies to underline that the list of core competencies of organisations' (pathfinding ${ }^{4}$ ) from Turner and Crawford [48] parallels to a great extent with the concept of foresight. This equivalence gives a logical argument for placing foresight among the competencies of the organisation.

Cunha et al. [42] similarly link foresight to the literature on business strategy, where strategy itself should be viewed as social practice or something that people do [49], and where organisational foresight can be viewed as a crucial organisational activity [50]. The authors mostly concentrate on explaining foresight as a social process, which confronts managers with the limits of their knowledge. The underlying assumption for such reasoning is the relationship between the decision makers' needs to know and the fear of knowing in the organisational foresight process. Cunha et al. conclude that it is necessary for managers to realise that organisational knowledge has a temporary validity and that plans are becoming outdated as they are implemented. Therefore, strategic foresight is a field undergoing a significant change, where organisations choose to focus on the present by developing intelligent and flexible organisational processes managed by outward-looking managers, who search for novel solutions trying to escape from the perpetuating accustomed patterns of thinking and acting [42]. In this sense, the organisation is becoming the strategy rather than a result of strategy [42].

Bootz [45] explicitly links organisational foresight with organisational learning. The author investigates the ambivalence between foresight "attitude" (of managers) and foresight "activity." Foresight attitude refers to the cognitive dimensions of an anticipation and individual learning, whereas foresight activity means a collective process, which mobilises several actors and involves more interactive learning forms. Bootz's survey highlights that the impact of foresight in terms of organisational learning is based on the cognitive virtues of the foresight attitude, which facilitates the questioning of individual representations. In collective approaches (foresight activity), this attitude concerns either decision-makers or, more widely, all actors in the organisation. Bootz's analysis underscores that only works focusing on strategic scenario planning (Shell's approach) deal with organisational learning in an explicit way.

To sum up, Bootz points out the overall deficit of the analysis and understanding of the notion of organisational learning

\footnotetext{
${ }^{4}$ Pathfinding understood as "the corporate competence to identify, crystallise, and articulate achievable new directions for the firm. Part of the competence stems from an outward and future orientation of the firms' members and the intelligent use of systems and processes to empower this" [44].
} 
Fig. 2 An example of organizational scorecard in the Foresight Maturity Model by Grim [34]

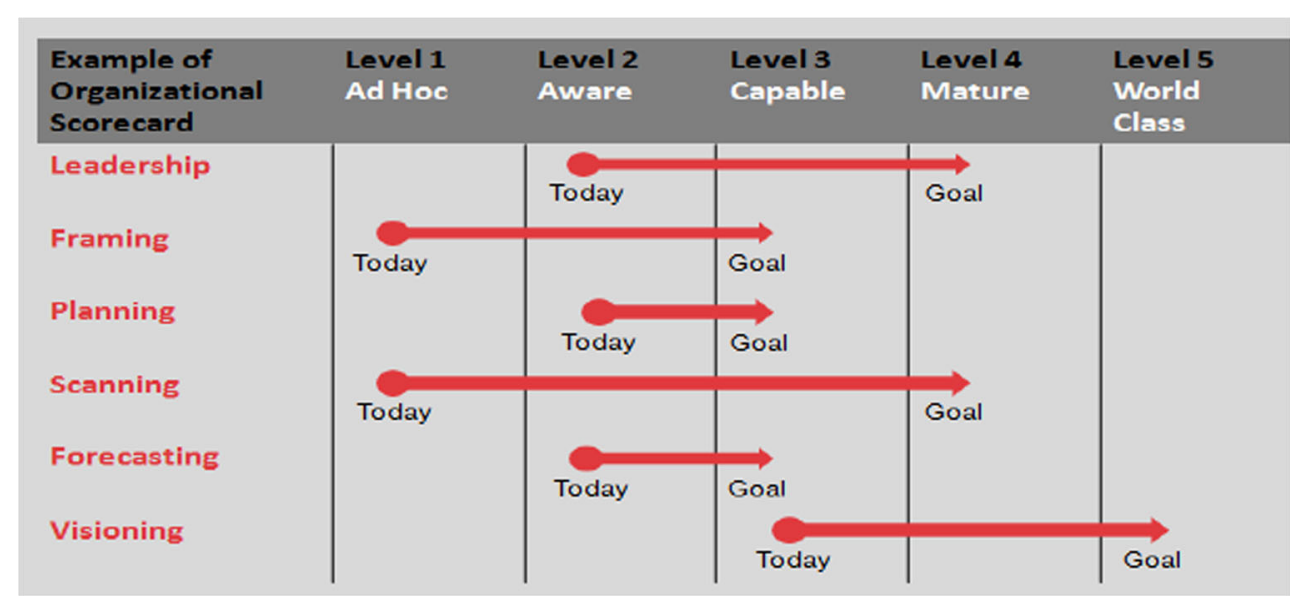

[45]. Cunha et al. point out the need to regard organisational foresight as a human process that is neither neutral or purely technical [42] and Major et al. claim that foresight has developed largely in isolation to the literature on business strategy [44].

The above-mentioned statements indicate the importance of further research that explores the connections between the strategy, foresight, and organisational culture.

\section{Foresight maturity model (FMM)}

Emphasizing the role of an organizational resource becomes a rationale for seeking models or tools that would enable one to assess foresight as a human or organizational competence. An interesting starting point could be capability maturity models, which are part of a class of models known as developmental models. Capability levels focus on growing the organization's ability to perform, control, and improve its performance in a process area. Capability levels enable one to track, evaluate, and demonstrate an organization's progress as it improves processes. Capability levels build on each other, providing a recommended order for approaching process improvement [34].

The foresight maturity model (FMM) developed by Grim [34] follows this logic. It provides a measurement tool, which enables organizations to assess their foresight capabilities against the model and identify where they need improvement. The example of the organizational scorecard is presented in Fig. 2.

The model takes into consideration such aspects as the following: leadership, framing, vision building, and planning defined as the ensuring that the plans, people, skills, and processes support the organizational vision.
The basic maturity model contains the following five (5) maturity levels [34]:

- Ad hoc (level 1). The organization is not or only marginally aware of processes and most work is done without plans or expertise. This is the initial state for any practice.

- Aware (level 2). The organization is aware that there are best practices in the field and is learning from external input and past experiences.

- Capable (level 3). The organization has reached a level where it has a consistent approach for a practice, used across the organization, which delivers an acceptable level of performance and return on investment.

- Mature (level 4). The organization has invested additional resources to develop expertise and advanced processes for a practice.

- World-class (level 5). The organization is considered a leader in this area, often creating and disseminating new methods.

These levels are developmental and cumulative. In other words, organizations can only achieve higher levels after they mastered and passed through the lower levels. As with any developmental process, there is no short cut [34].

The model provides a means to assess, reflect, and discuss current levels of foresight maturity and creates a language that promotes understanding both within organization and externally with other organizations. As such, it is a suitable tool to assess foresight maturity levels in companies regardless whether they are based in more or less developed regions.

In this context, the authors of the paper have made an attempt to investigate these issues in the empirical fieldwork executed in one of the least developed regions in Europe, namely the Podlaskie province. 


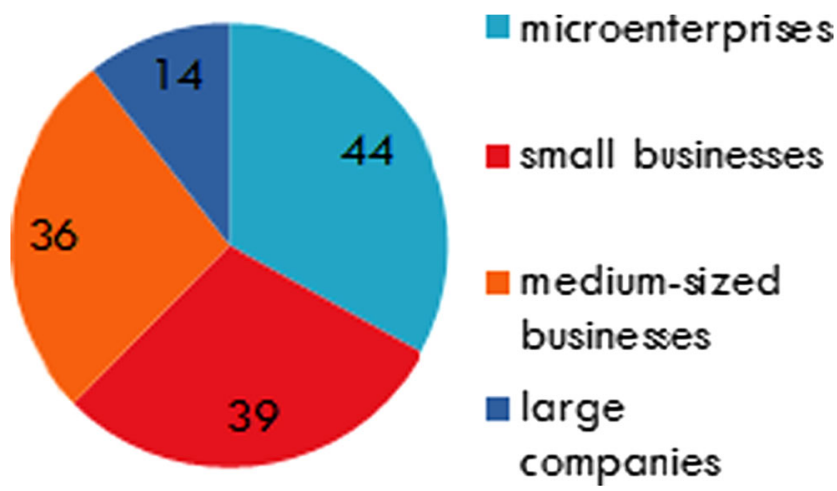

Fig. 3 The structure of the examined companies in respect to employment figures (Source: Authors)

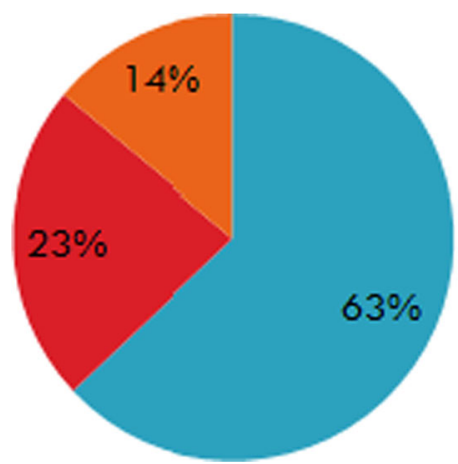

service companies

manufacturing companies

service and manufacturing companies

Fig. 4 The structure of the examined companies in respect to company type (Source: Authors)

\section{Podlaskie region - statistical characteristics}

Podlaskie region is located in the northeastern part of Poland. It is bordered by Lithuania and Belarus and therefore forms an internal (with Lithuania) and external (with Belarus) border of the EU. The Podlaskie region is one of the lowest economically developed regions of Poland (and of the European Union) with a low level of economic welfare, little business competitiveness, peripheral location in Poland, unsatisfactory transport accessibility, a weak internal market, and a low intensity of innovation in technology and product development [51]. The average GDP (in current prices) per capita in the region is almost $28 \%$ lower than the average GDP in Poland and ranks two hundred fifty fifth among two hundred seventy seven European regions. Podlaskie region accounted for $2.3 \%$ of Poland's total GDP in 2013 and is almost 10 times lower than those of Mazowieckie region, which was equal to $21.9 \%$ of total GDP [49]. Only $0.8 \%$ of production enterprises use advanced technologies, which gives the region one of the worst résumés in Poland ([51], p. 103).

The main reason for this situation is the weak capital power of the regional enterprises, which limits the expenditures on $R \& D$ [51]. The unemployment rate in the region equals $13.1 \%$ in comparison to the average unemployment rate of $11.7 \%$ in Poland [52]. The main industries of the Podlaskie region are machinery (agricultural machinery), textiles, wood products, and agri-business, including milk and milk processing (the production of butter and fats derived from milk account for $21.3 \%$ of domestic production), tobacco and beer production. Machinery and agriculture are also leading in R\&D expenditures [51]. Important factors activating the above-mentioned sector are cluster initiatives such as the Metal Processing Cluster, the Podlaskie Food Cluster, the Podlachia Lingerie Cluster, and the North-Eastern Wood Cluster. However, the development of traditional economic sectors contributes to regional economic growth to only a limited extent. Therefore, in order to transform the traditional businesses in Podlaskie province, the Technological foresight NT FOR* Podlaskie 2020 project was carried out with the aim of identifying the key nanotechnology research trajectories, which, applied in a business environment, would boost the economic development of the region. Despite
Fig. 5 Familiarity with the term foresight (Source: Authors)

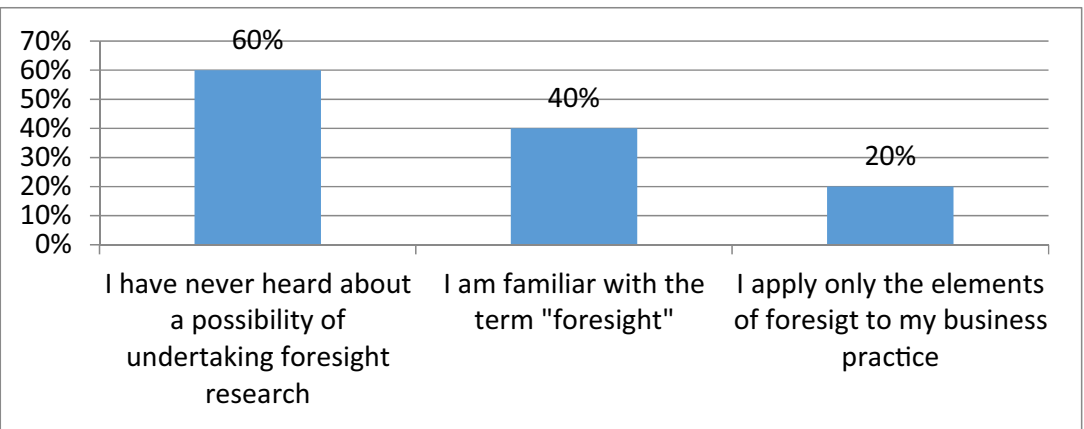


the orchestrated efforts and the resulting strategy agreed among the researchers, local entrepreneurs and politicians, the regional authorities have neglected the results of the project ${ }^{5}$ and chosen other smart specialization areas for the region. They included the following: High quality food, Life- sciences, Eco-innovations, Eco-development, and the "Silver economy" [53].

To sum up: the execution of regional foresight did not result in follow-up projects, where stakeholders (companies) would use the results of the NT FOR Podlaskie 2020 initiative to shape their development strategies based on nanotechnologies. Therefore, the authors of the paper (who were involved in the regional foresight process) agreed to empirically verify whether the foresight capability among companies in the region had been built, which in the long-term would be a starting point for testing a more bottom-up foresight approach (developing awareness and learning-by-doing foresight competence) that would better facilitate the development of local businesses and of the region itself.

\section{Survey research among enterprises in Podlaskie region}

The initial pilot study documented in the Polish language version by [54] was conducted in December 2013 and in January 2014 on a sample of 134 companies from Podlaskie region. The aim of the study was to assess the familiarity and application of foresight research as well as to assess foresight maturity with reference to the components identified by Grim [34]. The structure of the examined companies in respect to employment figures was the following: 44 microenterprises, 39 small businesses, 36 mediumsized businesses, and 14 large companies (Figs. 3 and 4).

Sixty-three percent of the companies analysed were service companies, $23 \%$ were manufacturing companies, and $14 \%$ were manufacturing and service companies. $60 \%$ of the businesses had never heard of a possibility of undertaking foresight research.

Enterprises' familiarity with the term foresight is presented in Fig. 5.

Familiarity with the term foresight was declared by $40 \%$ of the entrepreneurs. Twenty percent of the companies, mainly the large ones, and the ones that compete globally claimed application of foresight elements in their business practice.

The maturity level was calculated according to the following components of foresight maturity: leadership, planning, environmental scanning, forecasting, and vision building.

Figures 6 and 7 present the results of maturity levels in the planning and forecasting areas. These two areas have been chosen, because they present extreme results on maturity levels.

\footnotetext{
5 The project was led by the Management Faculty of Bialystok University of Technology within the EU Operational Programme "Innovative Economy 2007-2013" (Priority 1: "Research and development of modern technologies," Measure 1.1.: "Support for scientific research for establishment of a knowledge-based economy," Sub-measure 1.1.1: "Research projects using the foresight method." It was completed in June 2013.
}

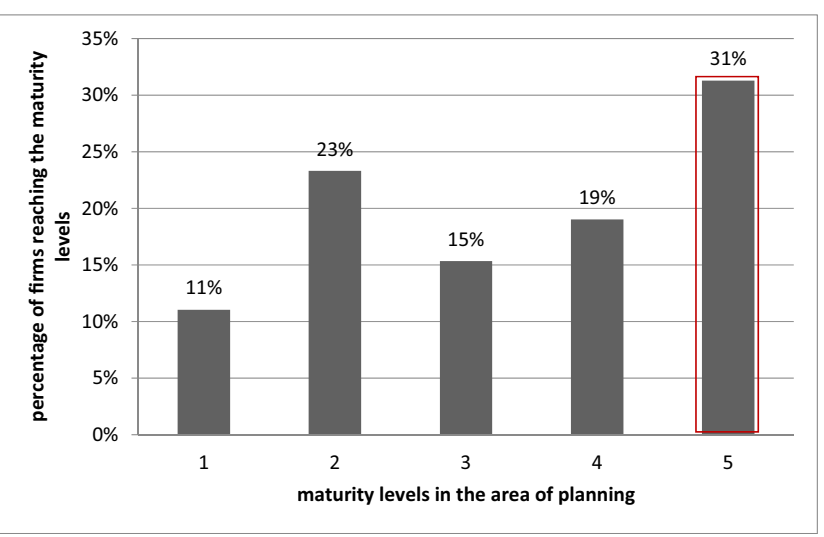

Fig. 6 The percentage of firms reaching the maturity levels in the planning area (Source: Authors)

For the purpose of the study, planning was defined as the ensuring that the plans, people, skills, and processes support the organizational vision. The description of each level of maturity in the area of planning is presented in Table 1.

The percentage of firms reaching the maturity levels is presented in Fig. 6.

In the planning area, the highest average foresight maturity level was attained. Thirty-one percent of enterprises declared that they were on the fifth level of maturity in this area. These were mainly large enterprises competing globally. Only $11 \%$ of the enterprises declared that they were on the first level of maturity.

Figure 7 presents the percentage of firms reaching the subsequent maturity levels in the forecasting area. For the purpose of the study, forecasting was defined as the description of long-term outcomes that contrast with the present to enable better decision-making. The description of each maturity level in the area of forecasting is presented in Table 2.

In the forecasting area, the lowest average maturity level was attained. Thirty-five percent of the enterprises declared that they were on the first level of maturity, $28 \%$ attained the second level. Only $5 \%$ of the firms declared that they were on the fifth level of maturity in this area.

Figure 8 presents the overall percentages of the enterprises reaching the five foresight maturity levels.

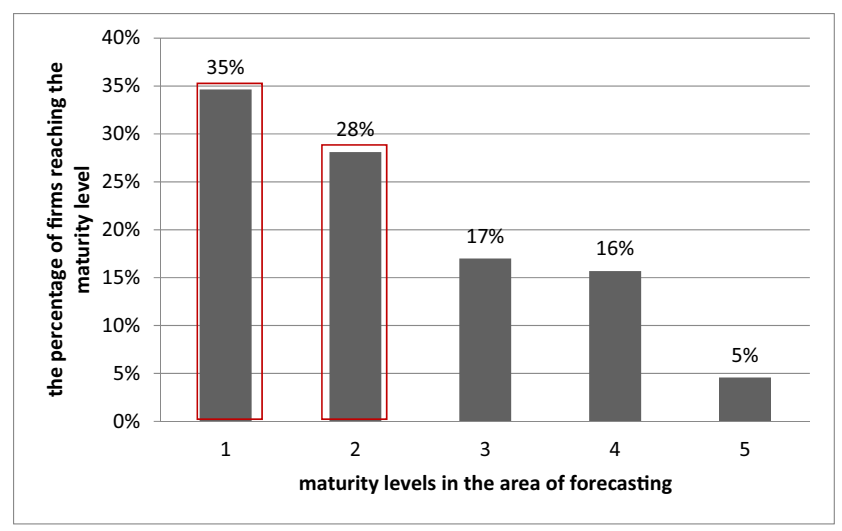

Fig. 7 The percentage of firms reaching the maturity levels in the forecasting area (Source: Authors) 
Table 1 Description of the maturity levels in the area of planning (Source: Authors)

\begin{tabular}{l}
$\begin{array}{l}\text { Maturity levels in the area of } \\
\text { planning }\end{array}$ \\
\hline $\begin{array}{l}\text { (ad hoc) } \\
2 \text { (aware) }\end{array}$ \\
$\begin{array}{l}\text { An enterprise assumes the future will be the continuation of the present. } \\
\text { An enterprise takes strategic actions and considers different strategies in a } \\
\text { periodic and unsystematic manner. } \\
\text { An enterprise has developed the process of the evaluation of the potential } \\
\text { strategies. The organization prepares formal plans and contingency plans } \\
\text { when the changes in the circumstances occur. }\end{array}$ \\
$\begin{array}{l}\text { A systematic process is used to routinely re-evaluate strategies, as new } \\
\text { information and feedback are available. Strategies are often tested before } \\
\text { implementation. }\end{array}$ \\
$\begin{array}{l}\text { Innovative new structures and policies have been created that engage the } \\
\text { ability of the "learning" organization to grow and adapt as it smoothly } \\
\text { executes well thought-out plans. }\end{array}$
\end{tabular}

The final foresight maturity level was calculated based on the lowest component value. The overall values of the subsequent maturity areas are presented in Table 3 . The score was calculated based on the dominant value of foresight maturity.

Since the lowest component value equals 1 for forecasting, the general foresight maturity of companies in Podlaskie region equals 1 .

\section{Discussion of the results and recommendations for further research}

The pilot survey has provided answers to research questions concerning the foresight maturity levels among companies based in one of the least developed regions in Europe. However, because many of the companies surveyed took part in the regional foresight project NT FOR Podlaskie 2020 and received learning-by-doing foresight experience, the overall result, which equals 1 , is surprising.

Due to limitations of this study, it is impossible to explain to what extent the low result depends on the (1) weak economic condition of the Podlaskie region itself or on the (2) composition of the study sample in which the majority of organisations surveyed were micro, small, or medium-sized companies (out of 134, only 14 were large companies).

To verify (1), a comparative study would have to be conducted in region(s) of similar economic characteristics and on similar samples of companies. Additionally, it would be interesting to assess foresight maturity levels among companies in top performing regions in Poland, or in Europe. Based on the results of such analyses, it would be possible to verify if the level of development of a region has an impact on the foresight capability of companies based in this region. Nevertheless, such a thorough analysis was out of the scope of the current study.

Regarding the composition of the sample (2), the comments received from the survey participants (regardless the size of the company) have indicated the following:

- The investment preference is given to product and process innovations that would quickly bring tangible results (that is profit).
Table 2 Description of the maturity levels in the area of forecasting (Source: Authors)

\begin{tabular}{ll}
\hline $\begin{array}{l}\text { Maturity levels in the area of } \\
\text { planning }\end{array}$ & Description \\
\hline 1 (ad hoc) & $\begin{array}{r}\text { Information is organized on the identifiable surface information. } \\
\text { Alternative futures are generally in the comfort zone of the probable } \\
\text { and are variations on the expected future for the domain of interest. } \\
\text { An enterprise considers the alternative future forecasts and gathers } \\
\text { additional information in order to support new, innovative ideas. } \\
\text { Plausible alternative futures are drawn from an analysis of all } \\
\text { contextual categories to understand broader possibilities for the } \\
\text { domain of interest. } \\
\text { A systematic process is in place to produce a set of alternative futures. } \\
\text { Each alternative is presented in a clear and comprehensive way. } \\
\text { An optimal set of alternative futures is generated. Each alternative } \\
\text { makes critical elements immediately apparent and the } \\
\text { accompanying depth provides unchallengeable support. }\end{array}$ \\
5 (world class) &
\end{tabular}


Fig. 8 The overall percentages of the enterprises reaching the five foresight maturity levels in the areas of leadership, planning, scanning, forecasting, and vision building (Source: Authors)

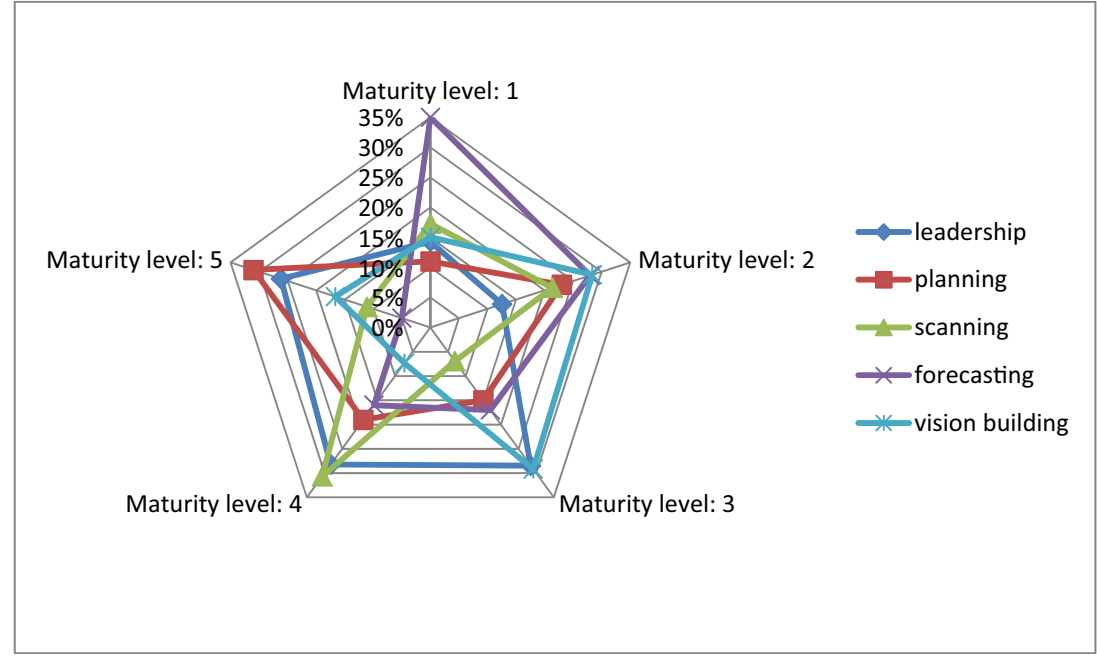

- Foresight practice is regarded as a time-consuming, capital- and labour-intensive organizational innovation that might (or might not) pay off in the long-term.

The comments lead to another research question. Should the innovativeness of products and services that a company offers (and not the size of the company itself) be a decisive factor when talking about the need to develop the organizational foresight capability? This line of reasoning gives way to another general question that could be posed. Should organizational foresight capability be built mainly among the innovation-intensive companies, as the ones that are most able to boost the development of the region itself? A positive answer would call for building a robust methodology for choosing the companies for the survey. However, the authors have purposefully chosen not to limit the group of potential beneficiaries of foresight.

As explained above, the study posed new research questions, which orientated the research towards two directions: (1) to propose and test ways to reach higher levels of foresight maturity in companies based in less developed regions willing to improve their foresight capabilities and (2) to enhance the Foresight Maturity Model itself.

Since this study only includes data from Polish companies, it would be advisable to include and compare data from similar surveys executed in other regions and countries. The data collected in such a multi-region survey would primarily enable one to identify interdependencies between the level of the

Table 3 The overall values of the subsequent maturity levels of enterprises in the Podlaskie region (Source: Authors)

\begin{tabular}{ll}
\hline Maturity levels & Maturity areas \\
\hline IV & Leadership \\
V & Planning \\
IV & Scanning \\
I & Forecasting \\
II & Vision building \\
\hline
\end{tabular}

development of the region and the foresight capability of companies, and secondly it would allow one to enhance the Foresight Maturity Model through the inclusion of other components that could result from specific national or regional contexts.

Since the Foresight Maturity Model lacks the techniques catalogue or best practices that would facilitate reaching the desired level of foresight maturity in areas such as leadership, planning, framing, scanning, forecasting and vision building, some recommendations of management concepts, which would improve foresight maturity in companies in underdeveloped regions (as the Podlaskie region), are given in the following section of the paper.

\section{Management concepts for the increase of foresight maturity levels in companies}

According to Savioz and Blum [55], the strategy of embedding foresight in the day-to-day activities of a company helps to create an "open minded company culture" that is favourable to foresight. Therefore, the active involvement of enterprises into foresight could be triggered by introducing the concepts of (1) employee empowerment [56] and (2) business coaching into strategic and HR management.

Mallon [56] lists 40 collective sets of values, processes and practices that influence and encourage continuous learning, and which are a substantial factor in both short-term business performance and long-term business growth. Best practices are divided into the following five categories ${ }^{6}$ :

1. Building Trust

2. Encouraging Reflection

3. Demonstrating Learning's Value

4. Enabling Knowledge Sharing

5. Formalizing Learning as a Process

$\overline{{ }^{6} \text { Full list of } 40}$ best practices can be found at: [57] 

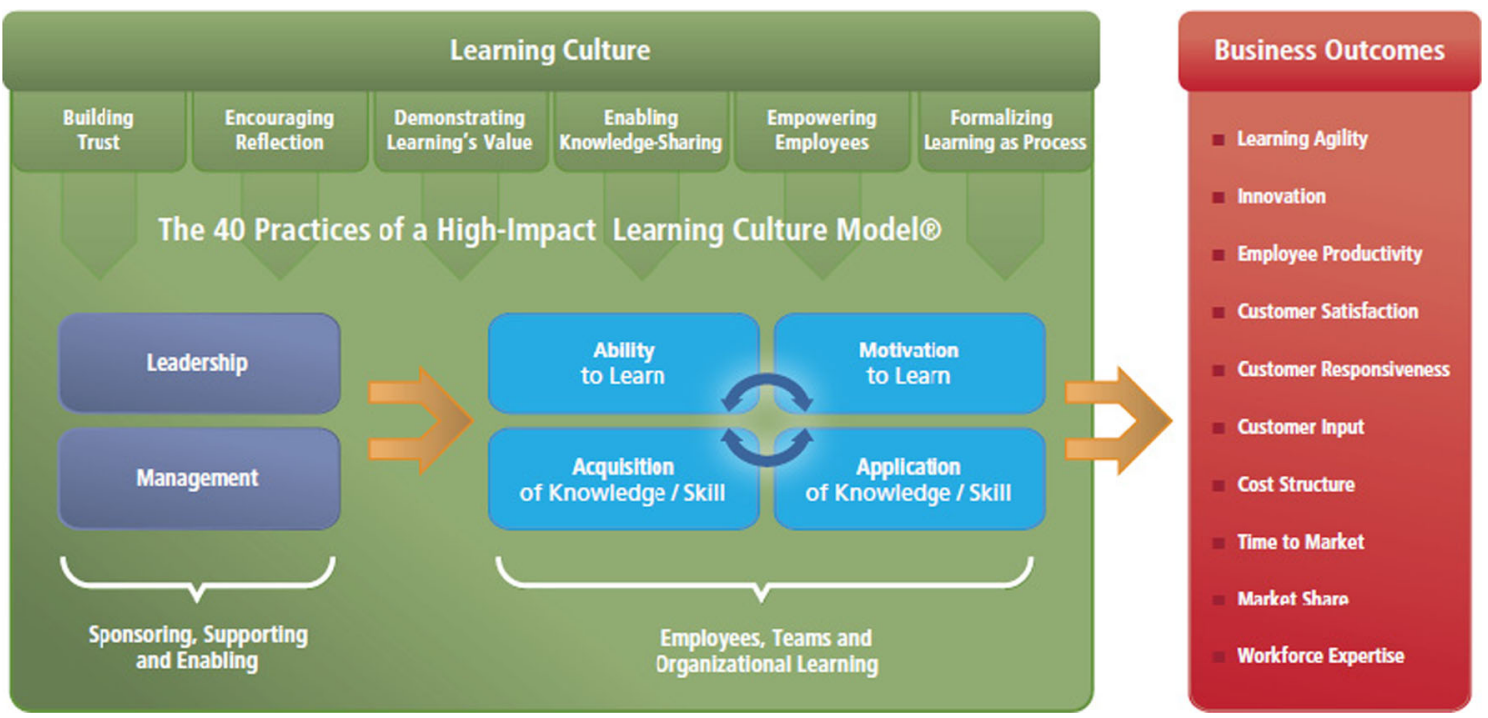

Fig. 9 Bersin \& Associates high-impact learning culture model (Source: ([58], p. 12))

[57] provides tools for firstly, defining and identifying the existing practices and elements of learning culture; and, secondly, taking action to improve these practices and processes to drive toward a "high-impact" culture. A High-Impact Learning Culture Model is proposed in [58] (Fig. 9), which lists business outcomes achieved with its implementation, and the list of business outcomes could easily be widened by the inclusion of foresight expertise.

Due to the low foresight maturity index of companies in the Podlaskie region, the application of the high-impact learning culture model [56] leading to an increase in company efficiency in the aspect of a chosen component or all components of foresight maturity seems substantiated.

Business coaching is the second management concept recommended by the authors of the paper, which would be instrumental to introducing the high-impact learning culture model and the attaining of the desired level of

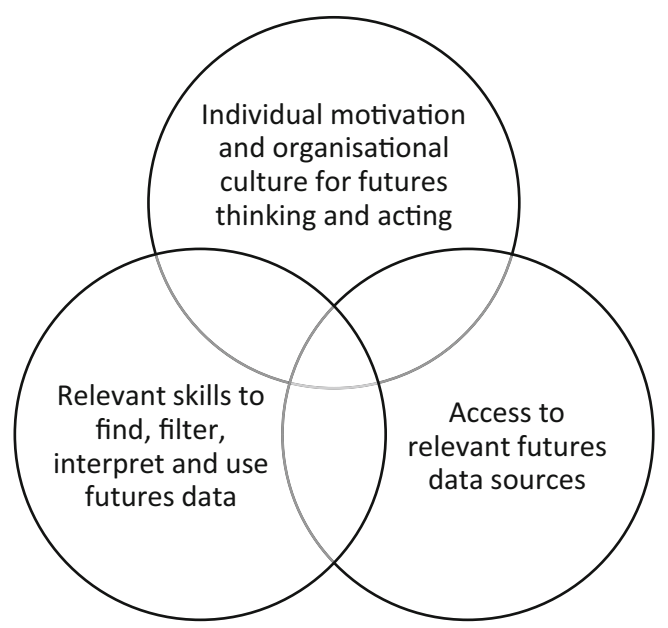

Fig. 10 Success factors of corporate foresight (Source: Authors) foresight maturity. The advantages of the coaching method are the following: the increasing effectiveness of entire companies, the optimization of decision-making processes, and more effective change management [59]. These advantages are naturally inherent in the concept of corporate foresight. Practicable coaching models are behavioural coaching based on the GROW model [57], a coaching model oriented to searching for solutions [60], and integrative coaching $[61,62]$. In addition to the above mentioned advantages of the method, coaching has been recognized and is now being promoted by the European Commission, which, in the framework of the Horizon 2020 scientific research programme, has launched three calls for proposals under the Industrial Leadership pillar [63] in order to enhance the innovation capacity of companies through coaching services and through the implementation of an SME instrument that includes business coaching itself [64].

\section{Concluding remarks}

The paper argues that the role of individuals is pivotal to the building of a company's competitive advantage based on foresight as one of its core competences. Obviously, it does not mean that intrinsic motivation of company managers or staff will suffice to implement a successful foresight orientation paradigm in an organization. Equally important will be relevant skills and relevant information sources related to futures data usage as shown in Fig. 10.

Therefore, the authors of the paper plan to continue the research in this direction to further develop the foresight maturity model, which could involve the means of equipping the employees of a company with skills to search for, 
interpret, and use the acquired futures knowledge through e.g., coaching methods and the use of already available training foresight toolkits, which could be adapted to specific national or regional requireme.

Open Access This article is distributed under the terms of the Creative Commons Attribution 4.0 International License (http:// creativecommons.org/licenses/by/4.0/), which permits unrestricted use, distribution, and reproduction in any medium, provided you give appropriate credit to the original author(s) and the source, provide a link to the Creative Commons license, and indicate if changes were made.

\section{References}

1. Rohrbeck R, Battistella C, Huizingh EKRE (2015) Corporate foresight: an emerging field with a rich tradition. Technol Forecast Soc Chang forthcoming. http://www.researchgate.net/publication/ 280942086

2. Gemunden HG, Salomo S, Holzle K (2007) Role models for radical innovations in times of open innovation. Creat Innov Manag 16(4): 408-421

3. von der Gracht HA, Vennemann CR, Darkow I-L (2010) Corporate foresight and innovation management: a portfolio-approach in evauating organizational development. Futures 42(4):380-393

4. Stadler C, Hinterhuber HH (2005) Shell, Siemens and Daimler Chrysler: leading change incompanies with strong values. Long Range Plan 38(5):467-484

5. Ejdys J (2013) Overcoming problems associated with uncertainty of the environment by using foresight approach. Econ Manag 13:331339

6. Nutt PC (2007) Intelligence gathering for decision making. Omega 35(5):604-622

7. Ejdys J, Kononiuk A (2013) Doskonalenie zarządzania strategicznego poprzez wykorzystanie koncepcji badań foresightowych. Przeglad Organizacji 1:8-13

8. Rohrbeck R (2010) Corporate foresight: towards a maturity model for the future orientation of a firm. Physica-Verlag, Springer, Heidelberg and New York

9. Alsan A (2008) Corporate foresight in emerging markets: action research at a multinational company in Turkey. Futures 40(1):4755. doi:10.1016/j.futures.2007.06.009

10. Sarpong D, Maclean M, Alexander E (2013) Organizing strategic foresight: a contextual practice of 'way finding'. Futures 53:33-41

11. Jarvis D (2012) Business foresight how companies explore the future, Regina University, MGT581 Business Foresight \& Futuring

12. Liebl F, Schwarz JO (2010) Normality of the future: trend diagnosis for strategic foresight. Futures 42(4):313-327

13. Vecchiato R, Roveda C (2010) Strategic foresight in corporate organisations: handling the effect and response uncertainty of technology and social drivers of change. Technol Forecast Soc Chang 77(9): 1527-1539

14. Tsoukas H, Sheperd J (2004) Coping with the future: developing organizational foresightfulness - introduction. Futures 36(2):137-144

15. Roney CW (2010) Intersections of strategic planning and futures studies: methodological compementaries. J Futur Stud 15(2):71-100

16. Rohrbeck R, Gemünden HG (2011) Corporate foresight: its three roles in enhancing the innovation capacity of a firm. Technol Forecast Soc Chang 78(2):231-243

17. Rohrbeck R, Schwartz O (2013) The value contribution of strategic foresight: insights from an empirical study of large European companies. Technol Forecast Soc Chang 80:1593-1606
18. Daft R, Weick KE (1984) Toward a model of organizations as interpretation systems. Acad Manag Rev 9(2):284-295

19. Lichtenthaler E (2005) The choice of technology intelligence methods in multinationals: towards a contingency approach. Int J Technol Manag 32(3-4):388-407

20. Rohrbeck R, Mahdjour S, Knab S, Frese T (2009) Benchmarking report: strategic foresight in multinational companies: European Corporate Foresight Group. http://papers.ssrn.com/sol3/Delivery. cfm/SSRN_ID1470050_code1332105.pdf?abstractid= 1470050\&mirid $=1$

21. Cuhls K, Johnston R (2006) Corporate FTA (Futureoriented Technology Analysis), Anchor Paper for the International FTA Seminar, Seville. http://foresight.jrc.ec.europa.eu/fta/documents/ anchor/FTA\%20Anchor\%20paperversion28-7rj\%20revn.pdf

22. Kuusi O, Cuhls K, Steinmuller K (2015) Quality criteria for scientific futures research. Futura

23. Poteralska B, Sacio-Szymańska A (2014) Evaluation of technology foresight projects. Eur J Futur Re 15:26. doi:10.1007/s40309-0130026-1

24. Kuusi O, Cuhls K, Steinmüller KH (2015) The futures map and its quality criteria. Eur J Futur Res 3

25. Keenan M, Marvin S, Winters C (2002) Mobilising the regional foresight potential for enlarged European Union, United Kingdom Country Report, Brussels

26. Clar G, Winters C (2003) The business of foresight. European Innovation ftp://ftp.cordis.europa.eu/pub/itt/docs/itt03-1_en.pdf

27. UNIDO Technology Foresight Manual Vol. 2 Technology foresight in Action, Vienna, 2005

28. Dannemand Andersen P, Borch K, Pedersen KO, Rasmussen B (2001) Virksomhedsorienteret teknologisk fremsyn. Rapport fra forprojektet Teknologi og Virksomhed i Fremtiden. Forskningscenter Risoe. http://orbit.dtu.dk/files/7728908/ris_r_ 1296.pdf

29. Hartman R, Philippens V (2004) ToekomstWijzer: a challenging method to make SME's aware of future trends, EU-US seminar: New Technology Foresight, Forecasting \& Assessment Methods, Seville

30. Georghiou L, Cassingena Harper J, Keenan M, Miles I, Popper R (2008) The handbook of technology foresight: concepts and practice. Prime series on research and innovation policy. Edward Elgar Publishing, Cheltenham

31. http://www.nistep.go.jp/en/

32. Cuhls K, Ganz W, Warnke P (2009) Foresight process - on behalf of the German Federal Ministry of Education and Research (BMBF) report new future fields. Fraunhofer ISI, Karlsruhe/ Stuttgart, http://www.isi.fraunhofer.de/isi-wAssets/docs/v/de/ publikationen/07_Dritter_Bericht_Teil-II_englisch.pdf

33. Kuusi O, Vasamo AL (2015) 100 opportunities for Finland and the world. Radical Technology Inquirer (RTI) for anticipation/ evaluation of technological breakthroughs, Publication of the Committee for the Future 11/2014, Helsinki

34. Grim $T$ (2009) Foresight maturity model, achieving best practices in the foresight field. J Futur Stud 13(4):69-80

35. Van Eck NJ, Waltman L (2007) VOS: a new method for visualizing similarities between objects. In: Lenz H-J, Decker R (eds) Advances in data analysis: Proceedings of the 30th Annual Conference of the German Classification Society. Springer, Berlin, pp 299-306

36. Van Eck NJ, Waltman L (2007) Bibliometric mapping of the computational intelligence field. Int J Uncertainty Fuzziness Knowledge Based Syst 15(5):625-645

37. Van Eck NJ, Waltman L (2010) Software survey: VOSviewer, a computer program for bibliometric mapping. Scientometrics 84(2):523-538 
38. Van Eck NJ, Waltman L, Noyons ECM, Buter RK (2010) Automatic term identification for bibliometric mapping. Scientometrics 82(3):581-596

39. Van Eck NJ, Waltman L (2009) VOSviewer Manual October

40. Van Eck NJ, Waltman L, Van den Berg J, Kaymak U (2006) Visualizing the computational intelligence field. IEEE Comput Intell Mag 1(4):6-10

41. Dobrzyński MD, Dziekoński K, Jurczuk A Analiza bibliometryczna artykułów w „Gospodarce Materiałowej i Logistyce z lat 20102012". Gospodarka Materiałowa i Logistyka, rok LXV, nr 12(1228):24-29

42. Cunha MP, Palma P, Costa N (2006) Fear of foresight: knowledge and ignorance in organizational foresight. Futures 38:942-955

43. Thom N (2010) Methods and tools of corporate technology foresight. Problemy Eksploatacji - Maintenance Problems, Vol. 3, ITeE - PIB, Radom http://yadda.icm.edu.pl/yadda/element/bwmeta1.element. baztech-article-BAR0-0056-0005/c/httpwww_bg_utp_edu_ plartpe32010pe32010057068.pdf

44. Major E, Asch D, Cordey-Hayes M (2001) Foresight as a core competence. Futures 33:91-107

45. Bootz JP (2010) Strategic foresight and organizational learning: a survey and critical analysis. Technol Forecast Soc Chang 77:1588-1594

46. Slaughter RA (1995) The foresight principle: cultural recovery in the 21st century. Adamantine, London

47. Prahalad CK, Hamel G (1990) The core competence of the corporation. Harv Bus Rev 79-91

48. Turner D, Crawford M (1994) Managing current and future competitive performance: the role of competence. In: Hamel G, Heene A (eds) Competence-based competition. Wiley, Chichester

49. Whittington R (2004) Strategy after modernism: recovering practice. Eur Manag Rev 1:62-68

50. Chia R (2004) The shaping of dominant modes of thought. Rediscovering the foundations of management knowledge. In: Jeffcut P (ed) The foundations of management knowledge. Routlege, London, pp 169-187

51. Nazarko J, Kedzior Z (eds) (2010) Uwarunkowania rozwoju nanotechnologii w województwie podlaskim. Wyniki analiz
STEEPVL i SWOT (Determinants of nanotechnology development in Podlaskie. The results of STEEPVL and SWOT). Oficyna Wydawnicza Politechniki Białostockiej, Białystok

52. http://www.stat.gov.pl/en/regional-statistics/

53. Strategy of Development of Bialystok City for 2011-2020 (in Polish: Strategia Rozwoju Miasta Białegostoku na lata 20112020 plus) http://www.bialystok.pl/resource/file/download-file/id. 452

54. Kononiuk A (2014) Foresight maturity of manufacturing and service companies (in Polish: Dojrzałość foresightowa przedsiębiorstw usługowych i produkcyjnych), Zeszyty Naukowe Politechniki Sląskiej, Seria Organizacja i Zarządzanie z. 73

55. Savioz P, Blum M (2002) Strategic foresight tool for SMEs: how the opportunity landscape interacts with business strategy to anticipate technological trends. Technovation 22:91-100

56. Mallon D (2010) High-impact learning culture: the 40 best practices for creating an empowered enterprise, (C) BERSIN \& ASSOCIATES RESEARCH REPORT | V.1.0

57. http://marketing.bersin.com/rs/bersin/images/Forty_Best_ Practices.pdf

58. Mallon D (2010) High-impact learning culture executive summary, (C) BERSIN \& ASSOCIATES RESEARCH REPORT | V.1.0. http:// marketing.bersin.com/rs/bersin/images/HighImpactLearning CultureES.pdf

59. Besser F, Wilson C (2012) What is coaching? (in Polish: Czym jest coaching?). In: Passmore J (ed) Excellence in coaching (in Polish: Coaching doskonały). Muza S.A, Warszawa

60. Alexander G, Renshaw B (2005) Supercoaching. Random House Business Books, London

61. Green LS, Oades LG, Grant AM (2006) Cognitive behavioural, solution-focused life coaching: enhancing goal striving, well-being and hope. J Posit Psychol 1(3):142-149

62. Passmore J (ed) (2012) Coaching doskonały. MUZA S.A, Warszawa

63. https://ec.europa.eu/research/participants/portal/desktop/en/ opportunities/h2020/topics/2346-innosup-9-2014.html

64. https://ec.europa.eu/easme/en/coaching-under-sme-instrument 